\title{
Diary of a Bird Watcher
}

Mrs. HAROLD BRAY, McLean

April 28 - There's plenty of snow today. Flocks of Tree Sparrows, Song Sparrows and Juncos are busy searching for food. Afternoon very stormy - every kind of bird, large and small flocking on bare spots on a burnt over stubble field. I am fearing for our feathered friends, Bluebirds in particular. One comes to shelter in a shallow hole in a telephone pole near the building every night.

April 29 - Better weather today; sun out but cold. Little songsters repaid me for sweeping snow off in sheltered spots where food was scattered - one near house where six or eight Robins were counted among a large flock of assorted Sparrows and Juncos - no quarrelling there. and what lovely chorus! Do Juncos ever sing or is it the Tree Sparrows we hear?

April 30 - Very low temperature and frost on trees. Where can our birds find food when there is from four to six inches of snow? A little Chickadee flew against a window pane, stunning itself, but after being picked up and left to rest in a plant box, flew away as good as new.

May 1 - It is still cold - 20 degrees above and light snow. Birds will soon be used to deep-freeze. The despised Buck-brush has provided food and shelter for countless little friends during their hour of need.
May 2 - What a relief! 32 degrees and warmer-snow going and Robins splashing around a sheltered slough - not so many songsters coming to feed - guess they are finding a more varied diet.

May 3, 4 and 5 - These few remarks conclude my short diary, with the return of warmer days and easier times for the birds. Saw a pair of Bluebirds around - glad some have survived, but one wonders about the numerous waterfowl which flew over a short time ago, such as the Whooping Crane. Here's hoping there's no more tragedy there.

Truly our feathered friends live in hazardous times and one feels powerless to help them much. Just saw a pair of what seemed to be Audubon Warblers. Are they common in our province?

P.S. - More hazards.

July 13 - We are slowly getting over the shock of last night's devastating hail storm which lasted scarcely ten minutes. Trees, shrubs, crops, etc. took a heavy beating. Our pair of Kingbirds who have nested here in the same nest for three years have come out the worst. The poor mother was killed on her nest and one young one. The male is around so I'm hoping he'll feed the one remaining alive. I don't know the extent of the destruction in this district but I fear the loss of birds nesting will be great.

\section{Impressions of Nature}

W. W. Carmichael, Clifton, N.B.

\section{What is more wonderful}

Than a bird's nest

Lined with silken hairs

Resting in the crutch

Of a gently swaying tree?

What is more majestic

Than the graceful beauty of a spruce

On a misty day?
Look! From her waving boughs She drops the pearls at our feet.

And a ray of sunshine

On a pile of sands

How those little gleaming eyes of mica

Wink and blink and wink!

The beauty of the last drooping aster,

Her curly fringes combed out by an angel;

She droops and faces the earth,

Yet she is looking at the sky

Reflected in a hundred dewdrops. 